\title{
Colon Atresia
}

National Cancer Institute

\section{Source}

National Cancer Institute. Colon Atresia. NCI Thesaurus. Code C101024.

A cong enital malformation characterized by the absence of a normal opening in a part of the colon. 